\title{
WILLIAM STUKELEY AND THE GOUT
}

\author{
by
}

\author{
KEVIN J. FRASER *
}

Gout was an ubiquitous disease in Georgian England. Although its victims were often immobilized at home for weeks on end, it was not, however, entirely unwelcome. Predominately a male disease, because of its frequency in the corridors of power and association with extravagant lifestyles, it was perceived as socially desirable. Moreover, there was the belief that the gouty were protected from more lifethreatening disorders such as palsy, dropsy or apoplexy. Physicians were therefore often reluctant to treat attacks of acute gout. Such therapeutic nihilism was convenient as gout had been considered the opprobrium medicorum since ancient times and many were prepared to suffer their attacks obediently. Others continued to search for a cure, looking beyond a disturbance of the four bodily humours for the cause of the disease. Pamphleteers fed the huge public appetite for such information, and the diaries and letters of the period contain frequent references to gout. However, these accounts often leave some uncertainty about the diagnosis, as most other forms of arthritis were yet to be distinguished from gout.

William Stukeley's descriptions of his own gout are, therefore, of particular importance, for they leave no doubt about the diagnosis. ${ }^{1}$ Not only do they provide

* Kevin J. Fraser, MBBS, MRCP(UK), FRACP, Medical History Unit and Department of Medicine, The University of Melbourne, Parkville 3052, Australia. Mailing Address: Austin Private Consulting Suite, 226 Burgundy Street, Heidelberg 3084, Victoria, Australia.

\section{ACKNOWLEDGEMENTS}

This work was made possible by the generous assistance of Mrs Elizabeth White (Texas Medical Center Library), Mr Geoffrey Davenport (Royal College of Physicians), Mr Steven Tomlinson (Bodleian Library), and Mr Alan Clark and Ms Sandra Cumming (Royal Society), Mr Norman Leveritt (Spalding Gentleman's Society) Mr Nicholas Muellner (Beinecke Rare Book and Manuscript Library, Yale University) and Dr Mark Nicholls (Cambridge University Library). I am grateful for their help and that of the editors and the referees, particularly David Harley who shared his detailed knowledge of the Stukeley manuscripts with me. I also wish to thank Professor George Rousseau for encouraging me to complete this project since I first discovered the links between Stukeley, Hill and Cadogan some years ago.

${ }^{1}$ W. Stukeley, A letter to Sir Hans Sloan Bart., about the cure of the gout by oyls externally apply'd, London, 1733 and $A$ treatise of the cause and cure of the gout, London, 1734. The dispersal of Stukeley's papers is discussed in detail by his biographer, S. Piggott, William Stukeley, an eighteenth-century antiquary, 2nd ed., London, Thames \& Hudson, 1985, pp. 168-9. Some of his letters were published by John Nichols, Illustrations of the literary history of the eighteenth century, London, 1817-58, 7 vols, hereinafter referred to as Lit. illus. Additional material was published by the Surtees Society: The family memoirs of the Rev. William Stukeley MD and the antiquarian and other correspondence of William Stukeley, Roger and Samuel Gale etc., 3 vols., Publications of the Surtees Society, 73, 1882, 76, 1883, and 80, 1887, hereinafter referred to as SS i, ii and iii respectively. The extensive holdings of the Bodleian Library (Bodl.) and small groups of letters held by the Spalding Gentlemen's Society (SGS) and the Beinecke Manuscript and Rare Book Room, Yale University Library (Osborn Files) have also been used in this study which is inspired by five of 


\section{William Stukeley and the gout}

insights into the disease from the podagric's perspective, but, as a physician, Stukeley thought deeply about its cause and cure, debunking much of the conventional physic. His sincerity in promoting "Dr. Rogers's Oleum Arthriticum, a specific oil for the gout" contrasts with the marketing of other such nostrums. He eventually despaired of its efficacy as a cure, placing his faith instead in preventive measures including exercise, temperance and dietary modifications.

Stukeley's medical career was not studied by his biographer, Piggott, who chose to concentrate on archaeological and antiquarian matters. An emphasis on his fascination with the Druids and a perceived eccentricity led to a diminished assessment of his worth, particularly in his later years. ${ }^{2}$ This has now been challenged as a result of a reinterpretation of Stukeley's archaeological studies which suggests that his speculation was not entirely fanciful and that he maintained objectivity within the bounds of contemporary knowledge. ${ }^{3}$ To regard his theories as far-fetched by modern standards is to engage in an anachronistic value judgement. This is not to say that Stukeley was not somewhat eccentric or that there was no criticism of him in his own time. However, it must be remembered that much of this came from political or religious opponents. ${ }^{4}$ The present study of his interest in gout portrays him as an astute and open-minded physician who, on the one hand, broke with the humoral tradition by proposing a specific disease mechanism and cure, and, on the other, enthusiastically embraced the Grecian precepts of regimen before it became fashionable to do so.

\section{STUKELEY AS PHYSICIAN AND VICAR}

Now remembered for his archaeological studies of Stonehenge and Avebury, Stukeley had first studied medicine at Bennet (later Corpus Christi) College, Cambridge where his friendship with Stephen Hales, a Fellow of the college, stimulated his interest in anatomical dissections, chemical experiments, astronomy and natural history. He also became interested in electricity as a result of Stephen Gray's demonstrations. ${ }^{5}$ Following his graduation in 1709, at the age of twenty-one, Stukeley studied under Dr Richard Mead at St Thomas's where he "formd a

Stukeley's manuscripts on gout, recently acquired by the Texas Medical Center Library, Houston, for the Burbank-Fraser Collection (BFC). For Stukeley's library see S. Piggott (ed.), 'Antiquaries', in Sale catalogues of libraries of eminent persons, vol. 10, London, Mansell, 1974, pp. 419-62.

${ }^{2}$ Piggott, ibid.

${ }^{3}$ P. Ucko, M. Hunter, A. Clark and A. David, Avebury reconsidered: from the 1660 s to the 1990 s, London, Unwin Hyman, 1991, pp. 94-8.

${ }^{4}$ SS, i, pp. 127-30, for Stukeley's account of his rel:tionship with William Warburton, indicating doctrinal differences, and W. Warburton to R. Hurd, 4 March 1765, in Nichols, op. cit., note 1 above, Lit. illus., ii, pp. 59-60, for Warburton's recollections of Stukeley as a simple, droll, absurd, ingenious and superstitious antiquarian. Thomas Hearne was even more damning, but he was an ardent Jacobite: SS, i, pp. 169-70.

5 J. Gascoigne, Cambridge in the age of the enlightenment, Cambridge University Press, 1989, pp. 159-63. Gascoigne's account of Stukeley's time at Corpus is based on the autobiographical accounts: W. Stukeley, 'Commentarys, 1720', SS, i, pp. 39-41 and 'Abstract of my life', SS, i, pp. 49-51. See also W. Stukeley to Ambrose Pimlow, 17 April 1705, in SS, i, pp. 142-4, regarding the curriculum at Bennet. Ambrose Pimlow and Stukeley were old school friends. Stephen Hales (1677-1761), MA (1703), BD (1711), DD (1733) Oxford. Elected FRS in 1718, he was the Copley medallist in 1739. He achieved lasting fame with his studies of plant and animal physiology. Stephen Gray's experiments on electricity led to the division of substances into conductors and non-conductors. He was elected FRS in 1732 and died in 1736. 
weekly meeting of the young Physicians \& Surgeons (Mr. Cheselden \& Mr. Tho. Forster), where we dissected some part or other, \& read a Discourse in our Turns upon any subject we had a Mind."6

In March 1710 Stukeley left London to practice in Boston, Lincolnshire. His attempts to cultivate patronage by engaging in "party squabbles", siding with the Tories (High Church), were unsuccessful. He then sought to establish a reputation in other scientific areas, particularly antiquarian studies, astronomy, mathematics and philosophy. ${ }^{7}$ When he returned to London in 1717 , he was a founding Fellow of the Society of Antiquaries and its first secretary. The following year he was elected to the Royal Society on the same day as Stephen Hales. Stukeley was proposed by Edmond Halley and was evidently well thought of, as, a week before the election, he was allowed to propose Hales. ${ }^{8}$ Then, in 1719 , he was persuaded to join the College of Physicians: "my fr[ien]ds forc'd me into the College to help to strengthen it." 9 At the time, the influence of the College was at a low ebb. Its fight to create a medical monopoly had been lost and, to many physicians, the College was irrelevant in an increasingly pluralistic environment, in which regular practitioners competed with apothecaries and irregulars for patients. ${ }^{10}$

Stukeley's influential acquaintances, who included Newton, Halley and Wren, were not always prepared to intercede on his behalf. He was bitterly disappointed in November 1721, when Sir Hans Sloane, Dr Richard Mead and "the whole Mathematical Party" opposed him in the election for Secretary to the Royal Society, won by Dr James Jurin. ${ }^{11}$ Stukeley delivered the Goulstonian lectures at the College of Physicians in 1722, on the spleen, but, lacking wealthy patrons and unwilling to solicit work in the taverns and coffee houses as George Cheyne and others had done, he failed to establish a successful medical practice. He claimed that he preferred a contemplative lifestyle to the "empty nonsense of coffee house chit chat, \& public company". ${ }^{2}$ While practitioners like Sloane and Mead had incomes of more than $£ 5000$ per annum, Stukeley denied any interest in the financial rewards of medical practice and criticized his colleagues in the College for "their gaudy life, \& sumptuous entertainments."13

${ }^{6}$ Idem., 'Commentarys, 1720', pp. 46-7. Stukeley read papers on Generation, Fevers, Tobacco and the Forms of Prescription. William Cheselden (1688-1752), surgeon and anatomist, was apprenticed to $\mathrm{Mr}$ Ferne at St Thomas's c. 1703. He was appointed lecturer in anatomy in 1711 and surgeon to St Thomas's in 1719. Mr Thomas Forster has not been identified with certainty.

${ }^{7}$ W. Stukeley, 'Events under planetary influence', SS, i, pp. 91-2. See Gascoigne, op. cit., note 5 above, pp. 71-114 regarding political and religious influences at Cambridge; predominantly Tory (High Church) in Stukeley's student days, the Whigs (Latitudinarian) were in the ascendency by the 1720 s.

${ }^{8}$ Royal Society: JBC. 11: pp. 214 (Stukeley proposed), 227 (Hales proposed), 228 (Stukeley and Hales elected).

${ }^{9}$ Bodl. MS Eng. misc. e. 121, f.30.

${ }^{10}$ G. Holmes, Augustan England, professions, state and society, 1680-1730, London, Allen \& Unwin, 1982 , pp. 170-1. See also D. Porter and R. Porter, Patient's progress: doctors and doctoring in eighteenth-century England, Cambridge, Polity Press, 1989, pp. 18-22.

${ }^{11}$ W. Stukeley, 'Diary', SS, i, p. 65. James Jurin (1684-1750) received his medical training at Cambridge, becoming MD (1716). He was physician to Guy's Hospital (1725-32) and was elected to the Royal Society in 1718, where he was second secretary, 1721-27.

12 Bodl. MS Eng. misc. e. 121, f.27. For George Cheyne see R. Porter (ed.), George Cheyne: The English malady (1733), London, Routledge, 1991, p. xvi.

${ }^{13}$ Ibid., f.29. See Holmes, op. cit., note 10 above, pp. 222-3 regarding Sloane and Mead. 


\section{William Stukeley and the gout}

Disillusioned with London, which he felt was "voy'd of religion", Stukeley moved to Grantham, in 1726, where he hoped that he would have more success as a physician, while still having time to pursue his antiquarian interests. ${ }^{14}$ In addition, he was suffering from frequent attacks of gout and hoped that the country air and exercise would help his arthritis. After some initial success in medical practice, earning about $£ 200-£ 300$ per annum, which was "quantum sufficit" for Stukeley, and average for a provincial physician, his income progressively fell and by 1729 it was only $£ 50$ per annum:

though there is no other physician within less than 16 mile of me, yet I am scarce wanted once in a month, the country, generally, using Apothecarys ... ${ }^{15}$

The apothecaries' popularity was partly due to their numbers and lower fees, but also to a general recognition of their abilities, so that even the gentry availed themselves of their services. To make matters worse for Stukeley, he was in competition with his brother, Adlard, an apothecary, who was engaged by the Duke of Rutland. ${ }^{16}$

Stukeley resolved his dilemma by entering the Church. In June 1729, he wrote to Archbishop Wake seeking ordination in the Church of England. ${ }^{17}$ By then, Stukeley's antiquarian studies had led to an obsession with the Druids and an analysis of their religion, leading to "some notions about the Doctrine of the Trinity which I think are not common". ${ }^{18}$ Despite this, Wake felt that Stukeley's learning would compensate for a lack of formal training in divinity and, having thrown off his high church leanings, he was welcomed as a latitudinarian and was ordained in July $1729 .{ }^{19}$

The Church was overcrowded in Augustan England and livings, which usually paid about $£ 80-200$ per annum, were generally difficult to obtain. ${ }^{20}$ Stukeley lobbied his contacts amongst the gentry and, in October 1729, despite considerable high church opposition, the Lord Chancellor appointed him to All Saints in Stamford, where the stipend was $£ 110$ per annum. ${ }^{21}$ His financial situation was further improved in 1739 ,

14 Bodl. MS Eng. misc. e. 126, ff.82-3. W. Stukeley to H. Sloane, 6 December 1726, in SS, ii, pp. $259-60$.

${ }^{15}$ W. Stukeley to S. Gale, 25 October 1727, in SS, i, pp. 198-200 for his initial income. W. Stukeley to R. Gale, 22 April 1729, in SS, ii, pp. 263-4 and W. Stukeley to H. Sloane, 24 September 1729, in SS, ii, pp. 264-5 regarding his declining fortunes. His reference to apothecaries is in W. Stukeley to Archbishop Wake, 3 June 1729, in SS, i, pp. 216-17. For a consideration of the income of country practitioners see Holmes, op. cit., note 10 above, p. 225 and Irvine Loudon, 'The nature of provincial medical practice in eighteenth-century England', Med. Hist., 1985, 29: 1-32. Roger Gale (1672-1744), eldest son of Thomas Gale; President of the Society of Antiquaries and Treasurer of the Royal Society. Samuel Gale (1682-1754), antiquary, younger brother of Roger. Stukeley's first wife, Frances, died in 1737. In 1739 he married Gale's sister, Elizabeth. William Wake (1657-1737), Archbishop of Canterbury, 1715-1737.

${ }^{16}$ Stukeley to Sloane, op. cit., note 14 above. See also Bodl. MS Eng. misc. e. 260, f.89. Stukeley had arranged for Adlard (1693-1752) to serve his apprenticeship with a Mr Cooper, of Northton: W. Stukeley, 'Commentarys, 1720', SS, i, p. 48.

${ }^{17}$ Stukeley to Wake, op. cit., note 15 above.

18 Ibid.

${ }^{19}$ W. Wake to W. Stukeley, 10 June 1729, in SS, i, pp. 217-19. See W. Stukeley, 'A bstract of my life', SS, i, p. 53 for his ordination by Wake at Croydon, 20 July 1729.

${ }^{20}$ Holmes, op. cit., note 10 above, for a discussion of preferment and the financial rewards of the church.

${ }^{21}$ Stukeley to Sloane, op. cit., note 15 above. The incumbent, Dr Rogers's brother, was terminally ill with dropsy. W. Canterbury (Wake) to W. Stukeley, 26 September 1729, in SS, i, pp. 224-5. W. Stukeley to F. Stukeley, 16 October 1729, in SS, i, pp. 225-6. For Stukeley's finances at Stamford, see Bodl. MS Eng. misc. e. 260, f.48v. 
when the Duke of Ancaster added the neighbouring living of Somerby, and in 1744, when he was appointed to the lectureship of All Saints. ${ }^{22}$ In 1730 he had canvassed the idea of seeking a living in London and standing again in the election for secretary to the Royal Society, following Dr Rutty's death. His friend, Roger Gale, advised him that Sir Hans Sloane would not support him. ${ }^{23}$ Stukeley persevered and asked Sloane to be his patron and to facilitate his transfer to London so that he could participate in the activities of the Royal Society. ${ }^{24}$ Nothing came of this and he remained at Stamford until he accepted the Duke of Montagu's offer of St George's, Queen Square, Bloomsbury, in $1748 .{ }^{25}$ Stukeley continued his antiquarian studies, and his major books, on Stonehenge and Avebury, were published while he was living at Stamford.

During the seventeenth century, religion and medicine were linked, especially by the Puritans, who stressed that, as the body was God's creation, there was a moral obligation to follow a healthy lifestyle. Disease was often seen as providential and punishment for sin, but, as God was a loving and benevolent being, the resultant paradox was at least partly rationalized by seeing his hand in the various cures. Although such interpretations were still common in the eighteenth century, they were by no means universal, particularly amongst Anglicans. Some physicians, like Richard Mead, and occasional clergymen questioned the literal interpretation of the Bible, attributing disease to physical causes rather than to evil spirits. ${ }^{26}$ Mead had abandoned religion and, for Stukeley at least, the consequences were obvious: "If they never seek to God, pay no addresses to him, he forsakes 'em \& the Devil takes 'em. This is universally the case of the Physicians, \& this makes the Dr. fall into the most abject instances of decrepid amours." 27 Stukeley's own views are recorded in his Croonian sermon, The healing of diseases, a character of the Messiah, preached before the Royal

\footnotetext{
${ }^{22}$ Holmes, op. cit., note 10 above, p. 102, discusses pluralism in clerical appointments, and endowed lectureships as a means of increasing incomes. See W. Stukeley, 'Abstract of my life', SS, i, p. 55, for Stukeley's appointment to Somerby and Bodl. MS Eng. misc. d. 719/22. f.17 for a meeting at Will's coffeehouse, Cornhill, when he was given the lectureship.

${ }^{23} \mathrm{R}$. Gale to W. Stukeley, 13 June, 19 June and 30 June 1730, in SS, i, pp. 233-7. William Rutty (1687-1730) studied medicine at Cambridge, MB (1712), MD (1719). Elected FRCP and FRS in 1720, he was the Goulstonian lecturer in 1725, on the urinary tract and its diseases. In 1727 he succeeded $\mathrm{Dr}$ James Jurin as second secretary to the Royal Society.

${ }^{24}$ W. Stukeley to Sir Hans Sloane, 30 December 1730, in Nichols, op. cit., note 1 above, Lit. illus., ii, pp. $793-4$

${ }^{25}$ W. Stukeley, 'Abstract of my life', SS, i, pp. 56-7.

${ }^{26} \mathrm{~A}$. Wear, 'Puritan perceptions of illness in seventeenth-century England' and J. Barry, 'Piety and the patient: medicine and religion in eighteenth-century Bristol', in R. Porter (ed.), Patients and practitioners: lay perceptions of medicine in pre-industrial society, Cambridge University Press, 1985, pp. 55-99, 145-75. For a discussion of the religious significance of disease see, R. Porter and D. Porter, In sickness and in health: the British experience, 1650-1850, London, Fourth Estate, 1988, pp. 166-82.

${ }^{27}$ W. Stukeley, 'Common-place Book', 1720, SS, i, pp. 111-12. Richard Mead (1673-1754) had studied medicine at Leyden and Padua and in 1707 gained his MD at Oxford. He was elected FRCP in 1716 and developed an extremely successful practice becoming physician-in-ordinary to George II. His book on poisons established his reputation and he was elected FRS in 1703. Mead's lechery was satirized in his lifetime: Old cornutor of seventy-five. Being a genuine narrative of the life, adventures, and amours, of Don Ricardo honeywater, London, 1748. Stukeley also blamed Martin Folkes (1690-1754), for "propagating the infidel System with great assiduity, \& made it even fashionable in the Royal Society, so that when any mention is made of Moses, of the deluge, of religion, Scriptures, \&c., it generally is received with a loud laugh.": 'Common-place Book', SS, i, pp. 98-100. Religious intolerance probably contributed to Stukeley's defeat in the election for secretary of the Royal Society, and was one of Stukeley's reasons for moving from London in 1726: op. cit., note 14 above.
} 


\title{
William Stukeley and the gout
}

College of Physicians in 1750 . He referred to the controversy about demoniacism [sic]: "'Tis degrading the dignity of Christ's divine mission, in a high degree, to spirit away the real, historical fact; in thinking it was only a disease." ${ }^{28}$ It was the concept of Christ the healer which had also served to link medicine and religion. This formed the basis of Stukeley's address and he pointed out "how much a religious physician may do, toward healing the moral diseases of his patient, as well as the natural. A truly glorious imitation of our blessed Savior's example!" 29 He saw disease as caused by "sin and folly" and the provision of "natural means" of cure as providential. ${ }^{30}$

At a practical level, country vicars were often expected to give medical advice to their parishioners, especially the poor. Their education, the popularization of medical knowledge and the widespread preoccupation with health and self medication meant that they were well placed to advise about common problems, such as melancholy. ${ }^{31}$ With his medical qualification, Stukeley would probably have been in particular demand and, although there is no mention of the poor, he certainly attended "some of the best Families in the Neighbourhood", apparently without charge. ${ }^{32}$ He maintained an interest in medicine in general, but he was best known as a gout doctor.

\section{STUKELEY'S OWN CASE OF THE GOUT}

Stukeley's first attack of gout was in 1709. As his father had suffered from the disease, Stukeley was convinced that he had an "hereditary title" to it. ${ }^{33}$ The initial attacks lasted a week or so, with remissions of up to two years, but, typically, they gradually became more frequent and more severe. After his return to London in 1717 he dined regularly with Dr Mead where he "drank nothing but french wine. so that I was every winter laid up with the gout: \& that sometime for 3 or 4 months together". 34 In March 1723 he described his suffering in graphic detail:

\begin{abstract}
After some vellications \& preludes the Gout seiz'd upon my right foot in the bones of the Tarsus. I let blood \& found it very much inflam'd, \& laid a Caustic upon the part, drinking much water $\&$ sugar $\&$ juice of lemon, fasting, $\&$ taking aloes every day. I made a crucial incision \& caus'd an issue where the Caustic was laid ... When I arose in the morning I found a slight touch as a prelude of the Gout in my great Toe of the left foot where it had been most frequently. But at night it went off, Fryday night or rather Saturday following, tho' I went very well to bed. About two a clock in the morning I wak'd with pain in my right instep where it never had been before, yet I walk'd about that day, next morning Sunday at the same hour It renew'd the attack in the same place with greater violence. When I gott up I order'd xvi oz. of blood to be taken away \& took
\end{abstract}

${ }^{28} \mathrm{~W}$. Stukeley, The healing of diseases, a character of the Messiah, being the anniversary sermon preached before the Royal College of Physicians, London; on September 20, 1750, London, 1750, p. 7.

${ }^{29}$ Ibid., p. 19.

${ }^{30}$ Ibid., p. 18.

${ }^{31}$ D. Porter and R. Porter, op. cit., note 10 above, p. 25. See also, Barry, op. cit., note 26 above, p. 69.

32 Bodl. MS Eng. misc. c. 314, f.30. Sir John Clerk to Roger Gale, in SS, iii, pp. 394-5, for the suggestion that Stukeley would not charge for his services. John Clerk (1684-1755), antiquary and advocate, succeeded as second baronet, 1722, MP in Scottish Parliament, 1702-7, and Judge of the Exchequer Court in Scotland, 1708-55. Bodl. MS Eng. misc. d. 719/7 f.16v records the visit of Colonel Kennedy "to consult about his case in the gout" in 1737.

${ }^{33}$ W. Stukeley, 'Commentarys, 1720 ' in SS, i, pp. 45-6. For his "hereditary title", see Stukeley, A treatise, op. cit., note 1 above, p. 38 .

${ }^{34}$ Bodl. MS Eng. misc. e. 121, f.28. 


\section{Kevin J. Fraser}

a good handsome dose of aloes lota as I had done the day before. I likewise order'd a Caustic to be laid upon the part but it prov'd not strong enough \& scarce made an escar, however we divided it by a cross section. Sunday night I was in pain again, but on Munday the swelling was abated \& pain gone. Munday night I took an opiate draught so that I slept perfectly well \& found no pain; but on tuesday morning the Surgeon took a fancy to lay on a soap plaster upon the wound which pain'd me all day \& night \& rais'd the inflammation higher so that it went to the last joint of the great toe of the right foot, passing by the great joynt, its former rendezvous, which was now encompass'd with it on both sides. The Swelling rose to a high degree even from toe to ancle, then I left off doing any thing at it, eat \& drank flesh \& wine, lay in bed two days... By advice of the Surgeon I bath'd my foot with oyl of turpentine and Rectif. Spirits of Wine which produc'd the gout in the other foot. This went thro the whole stadium as the other till they were reduc'd to an equality \& with equal pace by degrees came to their former state which was not perfectly done in less than 6 weeks. I was in a considerable fever all the time, great drought, my urine very high color'd \& thick, so that I conjecture if I had taken the bark as before it would certainly have taken off the fitt. ${ }^{35}$

The involvement of the great toe joints was classical, but even more telling from a diagnostic point of view are Stukeley's descriptions of peeling of the skin over the involved joints as the attacks resolved. ${ }^{36}$ Although most of his descriptions are consistent with articular gout, he, like all eighteenth-century physicians, believed that gout could affect vital organs. This occasionally happened in his case:

To morrow being the anniversary return of the gout it seiz'd me to night in the head; it lasted all night. Next day I walk'd all morning, rid all the afternoon; it comes now \& then as a violent cramp in the right tarsus, sometime as a crick in the neck, for that $I$ can plainly perceive a poison running about me. $^{37}$

It was generally believed that the gout was caused by a peccant humour, or toxic substance, which was being discharged from the involved joints. Contemporary treatments were designed to facilitate its removal from the body; sweating, bleeding, purging, vomits and artificial blisters produced by caustic substances were employed to this end. Such measures were commonly carried out under the direction of a physician or a surgeon but, like Stukeley, many patients also chose their own treatment, much to the chagrin of regular practitioners. ${ }^{38}$ Laudanum and paregoric, liquid forms of opium, were readily available and were effective anodynes and Sloane had popularized the use of quinine, for fever and to strengthen the nerves. ${ }^{39}$

${ }^{35}$ W. Stukeley, 'Diary', SS, i, pp. 69-71. Stukeley's surgeon may have been William Cheselden whom he visited occasionally: see for example, Bodl. MS Eng. misc. d. 719/4, f.25.

36 Stukeley, $A$ treatise, op. cit., note 1 above, p. 62.

${ }^{37}$ W. Stukeley, 'Diary, 1720', SS, i, p. 76. In 1757, Stukeley recorded that, "just as the moon was rising", his second wife, Elizabeth (op. cit., note 15 above) died "of the gout in her stomach": Bodl. MS Eng. misc. e. 137, f. 48 .

${ }^{38}$ For a discussion of community and professional attitudes to self-medication see R. Porter and D. Porter, op. cit., note 26 above, pp. 265-71 and D. Porter and R. Porter, op. cit., note 10 above, pp. 33-52.

39 Opium as an analgesic is discussed in R. Porter and D. Porter, op. cit., note 26 above, pp. 218-25 and D. Porter and R. Porter, op. cit., note 10 above, pp. 163-5. Sloane's popularization of quinine is discussed by E. St. John Brooks, Sir Hans Sloane. The great collector and his circle, London, Batchworth Press, 1954, pp. 87-8. 
For the next few years Stukeley had at least one severe attack annually. Although he continued to try whatever was current in physic, he gradually came to place more emphasis on regimen, moderating his diet and drinking several pints of milk or water daily, instead of alcohol, particularly during acute attacks of the gout. In April 1724, toward the end of another attack, which lasted about six weeks, he wrote:

I continued to drink water every day, by small quantitys at a time in morning, noon, after dinner, \& night, which kept the gout off, tho' I found every now \& then a tendency towards it. After waking in the night, I perceiv'd a constant inflammation of my blood, which went off soon after rising; now \& then after waking I found it, but a cup or two of water drove it off. I continued a pint of milk morning \& evening, but I conjecture water dos as well. ${ }^{40}$

He had been introduced to the idea of drinking water, rather than alcohol, with meals by Dr Edward Greathead, whom he had met in Boston in $1713 .{ }^{41} \mathrm{He}$ attributed this to providence, reflecting gratefully that the move to Boston led to the most important event in his life: "my finding out the means of subduing the gout". 42 Stukeley considered that water was "the universal diluent of our food", aiding digestion and promoting the excretion of "caustic salts" in sweat and urine. Milk was thought to have similar effects. ${ }^{43} \mathrm{He}$ frequently noted that his urine was concentrated during an attack, clearing as this resolved:

my water was plentiful, brown in color like London beer $\&$ with much red sedimt. the $2 \mathrm{~d}$. week it was of a fairer color but with the same sedimt. the $3 \mathrm{~d}$. week it was clear and citrine. $^{44}$

As a prophylactic measure he also favoured foods with diuretic properties, as "arthritics are slow of making water":

I take one great indication toward staving off the gout, is to apply such diuretics as are useful in its kindred distemper the gravel. Such are turneps, carrots, parsnips, etc. usd much in comon food $\&$ to be particularly careful in diet at spring $\&$ fall. when the blood $\&$ juices take a new turn. ${ }^{45}$

In considering gout, Stukeley adhered to the Georgian belief that there was a connection between health and weather conditions. ${ }^{46}$ Apart from any effect the change of seasons might have had, Stukeley's gout was generally worse in the winter months: "I attribute it to the eastern wind, so vehement $\&$ cold for many days before, which

${ }^{40}$ W. Stukeley, 'Diary', SS, i, p. 73.

${ }^{41}$ Bodl. MS Eng. misc. e. 121, f.25. See also, W. Stukeley to Lord Henley, 9 December 1758, BFC. A working draft, in Stukeley's handwriting, addressed 'To the Right honble the Lord Keep[er] \&c.'. There are fourteen leaves, measuring $155 \times 190 \mathrm{~mm}$, written on the rectos with emendations on the versos. Edward Greathead MD (d. 1745), of Lincoln.

42 Ibid.

${ }^{43}$ Stukeley to Henley, op. cit., note 41 above.

44 Bodl. MS Eng. misc. d. 719/2, f.8.

${ }^{45}$ Stukeley, $A$ treatise, op. cit., note 1 above, p. 110. Bodl. MS Eng. misc. d. 719/3, f.6, for the longer quotation.

${ }^{46}$ R. Porter and D. Porter, op. cit., note 26 above, pp. $156-8$. 
stopt insensible perspiration." 47 On another occasion, in January 1765, when the Archbishop of Canterbury, the Lord Chancellor, the Duke of Bedford, Mr Pitt and Stukeley all had the gout he blamed "severe cold eastern winds, rainy $\&$ moist weather succeeding, to produce the gout epidemically". ${ }^{48}$ By inhibiting perspiration, cold caused a critical build-up of the putative gouty toxin which, if the patient was lucky, was discharged into the joints, rather than the stomach, heart or brain. Stukeley followed convention in recommending measures such as oylsocks and diaphoretic medicines to promote perspiration. Physic, in the form of periodic emetics and purging, recommended by the ancient Greeks, was also used to eliminate the gouty toxin. Stukeley followed this practice himself: "I took a vomit by way of prevention of the fitt of the gout wh. I expect next month."49

Despite suffering from gout for over fifty years, Stukeley did not develop tophi or a destructive arthritis. On his seventy-fifth birthday, two years before he died after a stroke, he enthused about his state of health:

I have indeed all my senses perfect. \& the use of my limbs, in so surprising degree: considering, an hereditary gout began with me at 16 . held me for 30 years, with its full violence, no body, more. this extraordinary effect is owing to my own management, counter to the notion of all physicians. to their theory of the disease, or method of remedy. ${ }^{50}$

His management of the gout, which will now be discussed in more detail, was based on a moderate regimen, and the use of Dr Rogers's "Oleum Arthriticum, a specific oil for the gout".

\section{DR ROGERS'S GOUT OILS}

Stukeley believed that the hand of providence had directed him to Stamford. One of his parishioners, Dr John Rogers, an apothecary, who had been granted a bishop's licence to practise physic, had suffered from gout for years. Rogers was sometimes immobilized for six months at a time. In May 1729 he had begun to use a mixture of oils which he applied topically to the affected joints and this appeared to shorten the attacks. Similar results in his patients convinced him that he had found a cure. ${ }^{51}$

${ }^{47}$ Op. cit., note 35 above, p. 71.

${ }^{48}$ Bodl. MS Eng. misc. e. 140, ff.58-9. Thomas Secker (1693-1768), MD, Leyden, 1721, ordained 1723 , DCL, Oxford, 1733, was Archbishop of Canterbury, 1758-1768. John Russell (1710-1771) became the fourth Duke of Bedford in 1732. Politically active, he opposed Walpole. He was Lord Justice of Great Britain, 1745, 1748 and 1750. A Privy Councillor, he was Lord President from 1763-1767. He suffered from gout for over twenty years. William Pitt (1708-1778) entered parliament in 1735, Secretary of State 1756-1761 and 1766-1768. Created Earl of Chatham in 1766. Pitt's gout has been discussed by W. Graham and K. M. Graham, 'Our gouty past', Can. med. Assoc. J., 1955, 73: 485-93. Robert Henley (1708?-1772), Barrister, MP 1747-1757, the last Lord Keeper of the Great Seal 1757, Lord Chancellor 1761, first Earl of Northington, 1764. DNB records that Henley was "frequently incapacitated from his duties by repeated attacks of gout". See Holmes, op. cit., note 10 above, p. 121 for the office of Lord Keeper.

${ }^{49}$ Stukeley, A treatise, pp. 110-11. For Stukeley's own case, see Bodl. MS Eng. misc. d. 719/5, f.18v.

${ }^{50}$ Bodl. MS Eng. misc. e. 139, f.69.

51 Doctor Rogers's oleum arthriticum, or specifick oil for the gout, London, 1735. See also Bodl. MS Eng. misc. c. 314, f.27, a single printed page issued by Rogers to promote the oils. Stukeley's account of the discovery is in $A$ Treatise, op. cit., note 1 above, pp. 33-5. 


\section{William Stukeley and the gout}

From June until December 1732, Stukeley had recurrent attacks of gout and, on 11 December 1732, he decided to treat himself with Dr Rogers's oils for the gout, "with success, the first time". 52 They were then the talk of the town, as Dr Rogers had just recovered from a very severe attack of polyarticular gout. Stukeley persisted in his attempts to gain Sloane's favour by writing to him, reporting his success with the oils. The letter, 'About the Cure of the Gout, By Oyls externally apply'd', was read before the Royal Society on 1 February 1733 , and published later that year. ${ }^{53}$

Stukeley's explanation of the efficacy of the gout oils had to accommodate the belief that articular gout was beneficial: "'Tis plain, by throwing the morbific matter upon the extremities, she [nature] saves the individuum: relieving the whole by punishing a part." 54 Sydenham had warned that external medicines, as well as bleeding and purging, by suppressing articular gout, might cause what came to be known as "irregular gout" affecting internal organs. Stukeley reasoned that to oppose nature directly "is generally dangerous, but to assist her, safe and necessary". 55

Clopton Havers in his Osteologia Nova (1691) had proposed that the synovial villi were glands, producing mucilage, and that the synovial fluid was a mixture of this and an oily substance transmitted from the cavities of bones. The main function was joint lubrication, but Havers suggested that rheumatism and gout were caused by the action of morbific acid humours on the mucilage, causing it to coagulate. ${ }^{56}$ In extending this concept, Stukeley suggested that the function of the intra-articular oily substance was to neutralize the gouty humour. He proposed that the "fiery drop" of the gout was extinguished in the oil glands causing inflammation just as a piece of hot iron or charcoal immersed in oil sets it on fire:

By frequent fitts, all this oyly matter of the joint and tendons thereabouts, becomes deflagrated, and the glands that secrete it, so spoil'd in texture, that they cannot furnish a due quantity, either to lubricate the joint in walking, or to extinguish the matter of another fitt. Then nature is oblig'd to remand it to the next joint ... ${ }^{57}$

What could be more natural than to treat the gout by the external application of oils which, "like the oyly mucilage of the joints ... actually insinuate themselves to the part, and supply the use of the natural, by extinguishing this fiery drop . .."? ${ }^{58}$

Following Stukeley's initial report to the Royal Society, Dr Rogers issued a brief testimonial about the "Oleum Arthriticum" including directions for its use and announcing the availability of the oils at his own house in Stamford, or at his son's shop at the corner of Chancery Lane and Fleet Street, at $7 s .6 d$. a bottle. ${ }^{59} \mathrm{He}$ had not

52 Bodl. MS Eng. misc. d. 719/3, f.30.

${ }_{54}^{53}$ Stukeley, $A$ letter, op. cit., note 1 above.

54 Ibid., p. 10.

${ }^{55}$ Ibid., p. 18. T. Sydenham, On gout, in R. G. Latham (transl.), The works of Thomas Sydenham, MD, London, The Sydenham Society, 1848-50, 2 vols, vol. 2, pp. 131-2, 154. The emergence of the concept that disease could change location has been discussed by M. Nicholson, 'The metastatic theory of pathogenesis and the professional interests of the eighteenth-century physician', Med. Hist., 1988, 32: 277-300.

${ }^{56}$ G. P. Rodnan, T. G. Benedek and W. C. Panetta, 'The early history of synovia (joint fluid)', Ann. Int. Med., 1966, 65: 821-42.

${ }_{58}^{57}$ Stukeley, $A$ letter, op. cit., note 1 above, pp. 14-15.

${ }^{58}$ Ibid., p. 18.

${ }^{59}$ Bodl., op. cit.; note 51 above. 
intended to market the nostrum but was encouraged to do so by Stukeley, who further promoted it by reprinting his letter to Sir Hans Sloane together with $A$ Treatise of the Cause and Cure of the Gout, which went to press in January 1734. The printing of 1000 copies of the first edition cost Stukeley $£ 19$. The book was popular and, in 1735, there was a second edition and it was reprinted in Dublin. ${ }^{60}$ Stukeley stressed that he was acting independently of Rogers: "My sole view was to benefit the publick." 61

In the book, Stukeley expanded upon the circumstances of Dr Rogers's discovery and his own success with the oils, and, after an historical review of theories concerning the aetiology of gout, he proposed his own hypothesis. In Georgian times diseases were still often attributed to a disturbance of the four bodily humours. Gout seems to have been an exception and, about $150 \mathrm{AD}$, the Greek physician Aretaeus had suggested that it might be caused by a specific toxic substance. Paracelsus attempted to put this on a chemical basis, in proposing that gout was a disease of "tartar", which was a substance formed by the action of "salt" on a harmful indigestible substance entering from the outside. $^{62}$ In attempting to be more specific about the nature of such salts, which he believed were derived from food and were not dissolved by alcohol, Stukeley reasoned that the matter was a poison like that observed under the microscope by Dr Richard Mead in viper venom:

a parcel of small salts nimbly floating in a liquor and striking out into crystals of incredible tenuity and sharpness, he calls them spicula and darts. ${ }^{63}$

Mead had proposed oily substances as antidotes and, arguing by analogy, Stukeley suggested that Rogers's oils would "sheath the volatile salts of the venomous liquor, and prevent their shooting out into those chrystallin spicula which cause the deadly mischief', ${ }^{64}$ Stukeley was apparently unaware of van Leeuwenhoek's description of the needle shaped crystals in a gouty tophus, communicated to the Royal Society in January $1685 .^{65}$

Stukeley was convinced that the oil glands of the joint were the seat of the gout, and the discovery of some previous references to the use of various oils in the treatment of

\footnotetext{
${ }^{60}$ Stukeley, A treatise, op. cit., note 1 above. Stukeley's interleaved and extensively annotated copy was sold at Sotheby's on 15 July 1924, but unfortunately it cannot be traced. Bodl. MS Eng. misc. e. 667/5, ff.38-9 and, for the cost of printing see Bodl. MS Eng. misc. d. 719/18, f.3v.

61 Ibid., p. 30.

62 W. S. C. Copeman, A short history of the gout and the rheumatic diseases, Berkeley and Los Angeles, University of California Press, 1964, pp. 33, 52-3.

${ }^{63}$ Stukeley, $A$ treatise, op. cit., note 1 above, p. 65. His description was taken from Mead's book, $A$ mechanical account of poisons in several essays, London 1702, pp. 9-10. Stukeley did not allow his opinion of Mead's morals to interfere with his scientific objectivity: op. cit., note 27 above.

64 Ibid., p. 66.

${ }^{65}$ D. J. McCarty, 'A historical note: Leeuwenhoek's description of crystals from a gouty tophus', Arthritis Rheum., 1970, 13: 414-18. Although dated 25 July 1684 van Leeuwenhoek's letter to the Royal Society was not read until 7 January 1685, Royal Society, JBC. 6: 186. It was published as 'An abstract of a letter ... concerning the parts of the brain of severall animals; the chalk stones of the gout; the leprosy; and the scales of eeles' and included van Leeuwenhoek's drawings of the crystals: Phil. Trans., 1685, 15: 883-95. The chalk stone of the gout was subsequently identified as sodium urate by William Wollaston, 'On gouty and urinary concretions', Phil. Trans., 1797, 87: 386-400. For the pathogenetic role of sodium urate see
} 
gout served to reinforce his faith in Dr Rogers's particular preparation as "a speedy and perfect cure". ${ }^{66} \mathrm{He}$ was careful to separate the cure for the acute attack from the prevention of further attacks. Apart from being nature's own way of dealing with the gout poison, the oils were considered safe because they allowed for an early return to exercise, generally accepted as beneficial and, in this sense, were considered prophylactic. However, more important in this respect was temperance in diet and drink, "to prevent, as much as may be, the growth of these rich, sulphureous and inflamatory salts, in our blood". 67

In a paper which was read at the Royal Society on 31 January 1734, Stukeley gave an account of his forthcoming book. He anticipated criticism that he had not given the composition of the "Oleum Arthriticum" by claiming that "it became the Royal Society to encourage all useful discoverys, without being made acquainted with these secrets, which the inventors only have a right to". ${ }^{68}$ Sir Hans Sloane, who was critical of regular practitioners who peddled secret remedies, was evidently unimpressed when Stukeley wrote to him claiming that he had found the answer to the opprobrium medicorum, "as specific a remedy as any in the whole compass of the art of Physic; the greatest discovery ever made in the art in our own country". ${ }^{9}$ In 1734 Sloane, advising Richard Richardson, the Yorkshire doctor and naturalist, about the gout, noted "that patience and flannel are the best remedies". ${ }^{70}$ This was the most common advice given to the gouty, but some patients were unhappy with it. George Arnot wrote to Stukeley enquiring about the oils:

Now, pray, doctor, give me your opinion freely, if any good is to be expected from this new invention. All the comfort I have here from my physician is, patience, sir, \& flannel. Small comfort, God knows, in such an acute \& tedious distemper. ${ }^{71}$

Some weeks after the book appeared, Dr Thomas Wallis of Stamford wrote to the Royal Society giving a receipt for the composition of the "Oleum Arthriticum", as he believed that the poor had a right to know this, although he questioned the effectiveness of the nostrum. He claimed that it was originally intended for horses and that its use in man had caused irregular gout in one patient and death in others. ${ }^{72}$ Sloane refused Stukeley's angry demands for a copy of Wallis's letter. ${ }^{73}$ Undeterred, Stukeley based his reply, which was read to the Society on 24 May 1733, on what he had been told of it. He was noncommittal about the proposed composition and origin of the "Oleum Arthriticum", but denied any ill effects, refuting Wallis's claims and

J. E. Seegmiller, R . R. Howell and S. E. Malawista, 'The inflammatory reaction to sodium urate', JAMA, 1962, 180: 469-75.

${ }^{66}$ Stukeley, $A$ treatise, op. cit., note 1 above, p. 79.

67 Ibid., p. 103.

68 BL Birch Collection-Papers relating to the Royal Society MS 4432, f.306.

69 W. Stukeley to H. Sloane, 7 July 1733, in Nichols, op. cit., note 1 above, Lit. illus., ii, pp. 794-5.

${ }^{70}$ Brooks, op. cit., note 39 above, p. 85, for Sloane's attitude to secret remedies and p. 129 for his recommendations for gout. Richard Richardson (1663-1741), MD (Leyden) 1690, FRS (1712).

71 G. Arnot to W. Stukeley, 20 January 1735, in SS, i, pp. 277-8. Rev. George Arnot of Wakefield.

72 T. Wallis to C. Mortimer, 15 March 1733: Royal Society: EL.W3.155. Thomas Wallis MD(1698-1753).

${ }^{73}$ W. Stukeley to H. Sloane, 14 and 28 April 1733, in Nichols, op. cit., note 1 above, Lit. illus., ii, 794. 


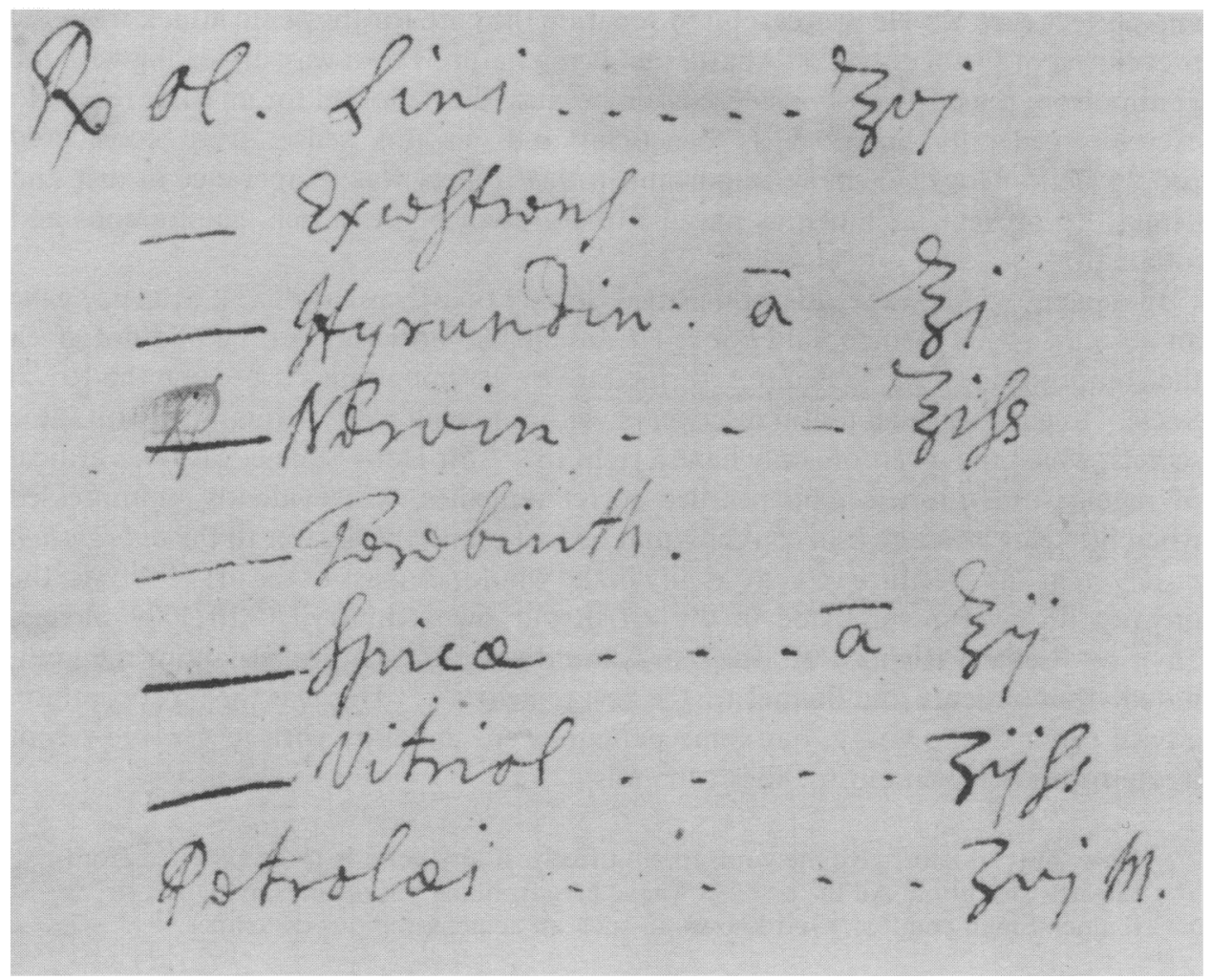

The composition of the "Oleum Arthriticum" as proposed by Dr Thomas Wallis in his letter to the Royal Society. According to him oleum spice was a mixture of oleum terebinthinae (oil of turpentine) and petrolei (Barbadoes tar). Oleum nervinum was unknown to Wallis and is not mentioned in contemporary pharmacopeias but oleum lini (oil of linseed), oleum vitrioli (sulphuric acid) and the compounded oils (oleum exestrense and oleum hirundinum) are included. Oleum terebinthinae and petrolei were the only components specifically recommended for topical use in rheumatic conditions. (Photo: The Royal Society).

giving an account of its successful use in other patients. ${ }^{74}$ Stukeley attributed such criticism to party squabbles:

Nevertheless the use of these oyls has been generally decry'd at home, and it took its share even in party-contests, as usual in the country. 'Tis not to be conceiv'd with what diligence and malice it was pursu'd here ... Tho' instances appear'd daily before their eyes, of its good effects; yet those were detorted and misrepresented as much as possible ... And those that had been wonderfully reliev'd by it, were suborn'd to deny it. $^{75}$

${ }^{74}$ W. Stukeley to Roger Gale, 5 May 1733, in Royal Society: LBC. 20: 176-182. Gale's scepticism as to whether the letter would be accepted, as Stukeley's "reflections upon the doctor's usage of you may be thought too severe", was evidently unwarranted: R. Gale to W. Stukeley, 11 May 1733, in SS, i, pp. 271-2.

${ }^{75}$ Stukeley, A treatise, op. cit., note 1 above, pp. 31-2. 


\section{William Stukeley and the gout}

Stukeley had switched his political allegiance to the Whigs after his time in Boston. Always eager to curry favour, he visited Sir Robert Walpole who had suffered from attacks of gout and gravel for many years: "I presented him with my book on Dr. Rogers's oyl. He receiv'd me with much candor \& said he would read it."76 Stukeley actively supported the Whig cause in Stamford during the bitter election of April 1734. He wrote an account of this for Walpole, in which he depicted Wallis as a Tory sympathiser. ${ }^{77}$ There were also religious differences and, to Stukeley, Wallis was a heathen. As Rogers was a Tory it seems most likely that Wallis opposed the oils for personal, rather than ideological, reasons. ${ }^{78}$ There was no paper warfare and the dispute about the gout oils certainly did not reach the heights of other partisan medical debates of the time concerning smallpox inoculation, rejected by the Tories for religious reasons, and George Berkeley's tar-water, ridiculed by the Whigs as a fraud. ${ }^{79}$

Stukeley was less concerned about criticisms in Dr Timothy Bennet's book, An Essay on the Gout, which also appeared in January 1734:

I saw Dr. Bennet's book of the gout, lately publishd, wherein he has animadverted upon me for my letter concerning Dr. Rogers's oyls; but very lamely. showing a strong desire to quarrel with me for it but with very weak argumentation. ${ }^{80}$

Bennet had berated Stukeley for suggesting that Rogers's oils might replace the "oily Mucilage of the Joints". 81 Many years later, Stukeley seemed to modify his theory by suggesting that the oils bring "that poysonous humor to the surface wh. otherwise must spend itself in the jo[i]nt". 82

More frustrating was the continuing concern that, by inhibiting perspiration, the oils might cause attacks of irregular gout. As late as 1741, Stukeley wrote of "the trifling objection agt my gout oyls, often raised by the ignorant: that they stop

\footnotetext{
${ }^{76}$ Bodl. MS Eng. misc. d. 719/4, f.13v. For Walpole's gout see, E. A. Spriggs, 'The illnesses and death of Robert Walpole', Med. Hist., 1982, 26: 421-8.

77 J. H. Plumb, Sir Robert Walpole. The King's minister, London, The Cresset Press, 1960, pp. 316-18. Stukeley's MS account for Walpole is listed in his library catalogue, Piggott, op. cit., note 1 above, p. 459, item 1023. The copy held in the Cambridge University Library, Cholmondeley (Houghton) papers, MS 68/11, is anonymous: for Wallis, see ff.6, 14 and 35. Despite his efforts in the Whig cause, Stukeley was unsuccessful in his attempts to be appointed as a chaplain-in-ordinary to the King (ibid., ff.12-13) and later complained to Edward Gibson, Bishop of London and Walpole's adviser on ecclesiastical appointments: E. Gibson to W. Stukeley, 6 January 1736, Osborn Files, 14.77.

${ }^{78}$ W. Stukeley, A treatise, op. cit., note 1 above, p. 33, for Rogers's political affiliation, and Bodl. MS Eng. misc. e. $667 / 5$, f.20 for Wallis, the heathen, abusing Stukeley and others at a meeting of the Stamford Book Club.

${ }^{79}$ There are two pertinent articles in A. Cunningham and R. French (eds), The medical enlightenment of the eighteenth century, Cambridge University Press, 1990. M. Benjamin, 'Medicine, morality and the politics of Berkeley's tar-water', pp. 165-93, highlights the importance of political and religious attitudes in determining the acceptance of new therapies. David Harley introduces a consideration of the subject of professional disputes in, 'Honour and property: the structure of professional disputes in eighteenth-century English medicine', pp. 138-64. See also R. Porter, 'Medicine and religion in eighteenth-century England: a case of conflict?', Ideas and Production, 1987, 7: 4-17.

${ }^{80}$ Bodl. MS Eng. misc. d. 719/18, f.3. Timothy Bennet (1703-?), MD(Leyden) 1725, practised at Norwich.

81 T. Bennet, An essay on the gout: in which a method is propos'd to relieve the hereditary, and to cure the acquir'd, London, 1734, pp. 121-2.

82 Bodl. MS Eng. misc. e. 133, ff.17-18.
} 
perspiration". ${ }^{83} \mathrm{He}$ was convinced that unction was not harmful. Soon after his book on Rogers's oils appeared, he noted an account in Philosophical Transactions, "of the oyl of the cinamon tree root curing the gout by unction. it seems to be slower in operation than ours". ${ }^{84}$ He was particularly heartened when his friend John Douglas, the surgeon, produced his own "Balsamum Arthriticum". Douglas claimed that it would "exceed Dr Roger's oyls, \& all the Medicines recommended by Ancients or Moderns in the Gout".85 Stukeley wished him well: "I shall be most heartily glad if any thing better than our oils can be discovered". ${ }^{86}$ He even tried the nostrum, which he identified as a mercurial preparation, himself:

16 sep. 1738. at 1 in the morn I was wakd by a gouty attack on my ankle. having some of Mr. Douglas's oyntment, I applyd a little \& it took it off. ${ }^{87}$

When Douglas's pamphlet $A$ short dissertation on the gout appeared in 1741 it contained several testimonials from Stukeley, including his declaration that: "In my opinion, my brethren, the physicians, have too much departed from the use of external applications, which was the chief practice of the antients". 88

After he returned to London in 1748, Stukeley hoped to influence his younger colleagues in the College of Physicians but, when he attended Comitia, they invoked a statute forbidding those who had taken Holy Orders from participating in College affairs. ${ }^{89}$ Soon afterwards, he took pleasure in telling a member of the College about one of his successes: "I have done that which the whole college can't doe, cur'd a fitt of the gout in a days time." 90 Although the faculty was sceptical, the oils remained topical and, in 1756, Stukeley was encouraged when Dr Pringle complimented him on his theories, supporting the principle of unction, even with "common oil, or palm-oil".91 At meetings of the Royal Society, and elsewhere, Stukeley was often greeted by people who praised the virtues of the oils, not only in gout, but also in various other complaints including sore throats, rheumatism and shoulder strain. ${ }^{92}$

Despite these encouraging reports, Stukeley continued to keep an open mind about

${ }^{83}$ Bodl. MSS Eng. misc. e. 387, f. 35 and e. 124 , f.45.

${ }^{84}$ Bodl. MS Eng. misc. d. 719/18, f.4. Phil. Trans., 1729, 36: 106-9.

${ }^{85}$ J. Douglas to W. Stukeley, 27 May 1738, Osborn Files: 11.67. John Douglas (d.1743), surgeon lithotomist to the Westminster Hospital, was involved in several professional disputes, including one with William Cheselden over the priority for an operation for bladder calculi.

${ }^{86} \mathrm{~J}$. Douglas, $A$ short dissertation on the gout, London, 1741, p. 18.

${ }^{87}$ Op. cit., note 85 above, Stukeley's annotation. See Bodl. MSS Eng. misc. e. 123, f.49 and e. 124, f. 82 for the ointment as a mercurial preparation.

${ }^{88}$ Op. cit., note 86 above, pp. 17-18.

${ }^{89}$ Bodl. MS Eng. misc. e. 127, ff. 17-20. See also SS, i, pp. 394-5 for Stukeley's letter, 29 March 1748, to Dr Richard Tyson, PRCP, protesting about this decision.

${ }^{90} \mathrm{~W}$. Stukeley, 'Memoirs of the gout oyls, 1740-1754', BFC. Six leaves, measuring $110 \times 170 \mathrm{~mm}$, being Stukeley's handwritten notes on the successful use of the oils, mainly accounts transmitted to him by others.

${ }^{91}$ Bodl. MS Eng. misc. e. 137, f.6. John Pringle (1707-1782), MD (Leyden) 1730, moved to London in 1748, after being Professor of Pneumatics and Moral Philosophy at Edinburgh, 1733-44. He became interested in military medicine after a period as Physician General to the forces in Flanders in 1744 and published Observations on the diseases of the army in 1752. Later honours included FRCP (1763), PRS (1772) and Physician to the King (1774). Knighted in 1766.

${ }_{92}$ Ibid., ff. 32, 50. For the more general use of the oil see op. cit., note 90 above. 
other remedies for gout, recording, for example, the use of guiacum in rum, which acted by causing mild diarrhoea or perspiration, ground ivy tea as a purgative and peppercorn or mustard seed to stimulate sweating. ${ }^{93}$ According to his theory of the gout it was not usually necessary to supplement the intra-articular oils for the first attack as they were not yet depleted. In 1748 Stukeley recalled that earlier methods of treatment were sometimes effective:

I dined with counsellor Wood, to whose family I was physician, when I lived in Ormond Street. he was siez'd with a fit of the gout. It was his first fit. I orderd him to be blooded, $\&$ to drink sassafras tea for a continuance: $\&$ he never had it since. ${ }^{94}$

Even in his own advanced case he did not always use the oils at the onset of mild attacks of the gout, sometimes trying water and a mild purgative first. ${ }^{95}$ When more than one joint was involved they were sometimes treated differently:

it began with me in a finger, we oil'd 3 times a day. it broke into a sore, \& was soon well. then it fell on the outside of my left foot. we oil'd 3 times a day, $\&$ it was soon well. it was in the outside of the right foot, but so moderately we did not think it worth oiling. but this was remarkable that it lasted longer in the unoiled foot, than in the oiled for 3 weeks. $^{96}$

This observation, which Stukeley made two months before he died, is consonant with his lifelong objectivity about the oils, even though he had gained a pecuniary interest in the product.

Rogers's agent for the sale of the gout oils was Alexander Cruden, the eccentric bookseller and author of $A$ complete concordance to the Holy Scriptures, who was to help Stukeley with several ventures over the years. ${ }^{97}$ In 1735 , Cruden published Rogers's brief account of himself and the oils, including directions for their use and several authentic testimonials, including a letter from a gentleman who spent three months in Stamford assessing their efficacy. This was republished, in part, the same year, as an appendix to the successful Dublin edition of Stukeley's book. ${ }^{98}$ The oils sold well, providing Rogers with an annual income of about $£ 300 .^{99}$ Stukeley

${ }^{93}$ Bodl. MSS Eng. misc. e. 125, ff. $37-8,47$ and d. 719/9, ff.3, 42, 46v.

94 Bodl. MS Eng. misc. e. 127, f.15. Stukeley lived in Ormond Street after he returned to London in 1717: Bodl. MS Eng. misc. d. 719/17, f.44.

${ }^{95}$ Bodl. MS Eng. misc. e. 133, f.15.

${ }^{96}$ Bodl. MS Eng. misc. e. 140, f.59.

${ }^{97}$ W. Stukeley to Henley, op. cit., note 41 above. Stukeley also arranged for Cruden to print a Diarium Religiosum, linking the Jewish and Julian calendars for 1738: Bodl. MSS Eng. misc. d. 719/18, f.11 and d. $719 / 7$, f.28v. In 1755 he had him prepare a catalogue of books in the library of St. Amand, a parishioner who had bequeathed them to the Bodleian Library: Piggott, op. cit., note 1 above, p.144. Cruden's biographer does not mention the links with Stukeley: Edith Olivier, The eccentric life of Alexander Cruden, London, Faber and Faber, 1934. For a consideration of Cruden's bouts of madness see R. Porter, A social history of madness, London, Weidenfeld and Nicolson, 1987, pp. 126-35.

${ }^{98} \mathrm{Op}$. cit., note 51 above. Mr. L-H, a gentleman who supplied a testimonial, is identified by Stukeley as Mr Hancock: Bodl. MS Eng. misc. d. 719/5, f.18v. See also, W. Stukeley, A letter . . and A treatise ... to which is added Doctor John Rogers's account of himself and his excellent remedy, Dublin, 1735. See pp. 67-76 for Rogers's account. The success of the oils and Stukeley's book in Ireland is covered in R. Gale to W. Stukeley, 16 September 1735 , in SS, i, pp. 279-80.

${ }_{99}$ Stukeley, to Henley, op. cit., note 41 above. 
introduced him to his circle of friends in London and, with Dr Tancred Robinson and Dr Andrew Hawes, arranged for him to be awarded the degree of Doctor in Physic from the University of Aberdeen. ${ }^{100} \mathrm{He}$ also suggested that Rogers be appointed to the Post Office of Stamford and received a sympathetic response from Sir Thomas Coke. ${ }^{101}$

Rogers died in 1739 , bequeathing the recipe for the gout oils to his daughter who was said to have rejected his dying wish to add a codicil including Dr Stukeley as a partner in this venture. On hearing this later, Stukeley decided to make oils himself, causing Miss Rogers to relent and in April 1740 they signed an agreement under the terms of which Stukeley was to prepare the oils according to Rogers's recipe. ${ }^{102}$ Later that year, Cruden issued a shorter version of Stukeley's book on gout, no doubt to promote the sale of the oils. ${ }^{103}$ An entry in Stukeley's diary of 1745 records a trip to London where he stayed with his brother-in-law, Samuel Gale, while making the oils. ${ }^{104}$ The oils remained popular and the preparation was sold in the East and West Indies, as well as in England and Ireland. ${ }^{105}$ There is no record of Stukeley's financial arrangement with Miss Rogers or of his income from the oils but, although his diaries record only occasional small payments from Mr Cruden, he invested thousands of pounds in South Sea stock and bank annuities, particularly after he returned to London. ${ }^{106}$ Stukeley believed that his book on the oils was a major contribution to mankind, and in 1743 he acknowledged his gratitude to Rogers by laying a plaque in his garden at Stamford. ${ }^{107}$

Although secret remedies smacked of quackery, and were frowned on by the faculty because they encouraged self-medication, some prominent members marketed their own nostrums. One of the most successful was James's Powder, a febrifuge based on oxide of antimony, which was patented by Dr Robert James in 1746 . However, the receipt sworn to in the patent was misleading and would not produce the powder. Similarly, Dr John Douglas did not disclose the composition of his "Balsamum Arthriticum", and there were others as well, including John Radcliffe, with "Royal Tincture, or the General Rectifier of the Nerves, Head and Stomach" and Richard Mead and his remedy for rabies. On the other hand, although Sir Hans Sloane also showed entrepreneurial flair by investing in quinine, he did publish the formula of an eye ointment which he promoted. ${ }^{108}$ Stukeley differed from most

\footnotetext{
${ }^{100}$ Bodl. MS Eng. misc. d. 719/6, f.11v, 18. Tancred Robinson (?-1748), was FRCP(1687) and FRS (1684). Andrew Hawes (1690-1769), was a surgeon and an apothecary.

${ }^{101}$ Lovell to W. Stukeley, 29 September 1734, Osborn files: 22.90. Thomas Coke was created Baron Lovell in 1728 and was appointed joint Postmaster General in 1733. In 1744 he was made Viscount Coke of Holkham and Earl of Leicester.

102 Bodl. MSS Eng. misc. d. 719/9, ff.25, 27 and e. 123, f.65.

${ }_{103} \mathrm{~W}$. Stukeley, An abstract of a treatise of the cause and cure of the gout, London, 1740.

104 Bodl. MSS Eng. misc. e. 195, f.17, and e. 121, f.56.

105 Stukeley to Henley, op. cit., note 41 above. See Bodl. MS Eng. misc. e. 134, f.36, for a shipment of the oils to the West Indies in 1754.

${ }^{106}$ For example, in February and March 1754 , Stukeley paid $£ 1000$ for old South Sea annuities: Bodl. MS Eng. misc. d. 719/13, f.3v, 4. He often dealt with Sampson Gideon (1699-1762), the Jewish financier: Bodl. MS Eng. misc. d. $719 / 12$, f.14.

${ }_{107}$ W. Stukeley, 'Common-place Book', SS, i, p. 106 and for the plaque, Bodl. MS Eng. misc. e. 196, p. 5.

108 D. Porter and R. Porter, op. cit., note 10 above, pp. 96-114 regarding popular nostrums and the relationships between regular and irregular practitioners and their patients. See J. K. Crellin, 'Dr. James's
} 
promoters of proprietary medicines by recommending the use of the oils on theoretical grounds, rather than relying on phony testimonials. The product itself was no better or worse than a number of other specifics for the gout, but a growing emphasis on the role of the constitution in determining the manifestations of disease resulted in a trend towards "holistic" therapeutics rather than specifics. 109

\section{REGIMEN AND GOUT}

Although Stukeley initially believed that he had found the cure of acute gout in the oils, he was under no illusion that these would also prevent future attacks. ${ }^{110} \mathrm{He}$ extended his interest in regimen, which he was already using in the acute attack, and tried to influence others to adopt a more moderate lifestyle as a preventive measure. The concept was not new. Self-help manuals in England dating from the sixteenth century were based on attention to regimen, particularly as it related to Galen's six non-naturals. According to this doctrine ill-health. resulted from perturbations of environmental factors and bodily functions concerning, air, diet, sleep, exercise, evacuations and peace of mind. ${ }^{111}$ Smith has traced the evolution of these neoHippocratic concerns from works on popular medicine by Elyot and Cornaro in the sixteenth century through to the eighteenth-century books by Cheyne, Wesley and Buchan. These were the forerunners of a genre which reached its fullest expression towards the end of the eighteenth century. ${ }^{112}$ George Cheyne's books on gout and melancholy, and his Essay of health and long life, were particularly popular amongst polite society (he was a fashionable Bath physician) and they were often mentioned in letters and diaries as well as being a talking point at social gatherings, even after his death in 1743. ${ }^{113}$ Wesley and Buchan wrote for the other end of the market, for those for whom self-help was a welcome alternative to costly professional care. At first sight Stukeley's involvement in this movement, which was generally spearheaded by Tory physicians, is surprising. ${ }^{114}$ However, it seems unlikely that he ever felt strongly about either political party, and his ambivalence was probably reinforced by his repeated failure to gain the sort of patronage that he desired.

Stukeley often accused booksellers of cheating authors and, although he was a prolific writer, he published relatively little. ${ }^{15} \mathrm{He}$ adopted a more personal and

fever powder', Trans. Brit. Soc. Hist. Pharm., 1971, 1: 136-43, for a detailed study of this nostrum. Brooks, op cit., note 39 above, pp. 85-7, for Sloane's ointment.

${ }^{109}$ R. Porter and D. Porter, op. cit., note 26 above, p. 144.

${ }^{110}$ Stukeley, $A$ treatise, op. cit., note 1 above, pp. 101-3.

111 P. H. Niebyl, 'The non-naturals', Bull. Hist. Med., 1971, 45: 486-92.

112 G. Smith, 'Prescribing the rules of health: Self-help and advice in the late eighteenth century' in Porter (ed.), op. cit., note 26 above, pp. 249-82.

${ }^{113}$ G. S. Rousseau, 'Mysticism and millenarianism: Immortal Doctor Cheyne', in I. Merkel and A. G. Debus (eds), Hermeticism and the renaissance: intellectual history and the occult in early modern Europe, Washington, D.C., The Folger Shakespeare Library, 1987, pp. 192-230. See T. McCrae, 'George Cheyne, an old London and Bath physician (1671-1743)', Johns Hopkins Hosp. Bull., Balt., 1904, 15: $84-94$ for detailed summaries of Cheyne's books. For a discussion of The English malady (1733) see Porter, op. cit., note 12 above, pp. ix-li.

114 Barry, op. cit., note 26 above, p. 170.

115 W. Stukeley, 'Abstract of my life', SS, i, p. 58. This was not vanity on Stukeley's part as suggested by W. Langdon-Brown, Some chapters in Cambridge medical history, Cambridge University Press, 1946, pp. 70-2. Other authors made similar complaints: see, for example, C. F. Mullett (ed.), 'The letters of Doctor George 
selective approach, sending unsolicited manuscripts on a variety of scientific, antiquarian, medical and religious topics to friends, acquaintances and public figures. A series of such letters about regimen in the gout, particularly as it related to diet, reveal a gradual shift in emphasis from cure to prevention. In February 1741, he visited Robert Butts, the Bishop of Ely, who was "very ill of the gout"; he returned on March 7 and again, at the Bishop's invitation, on July 20 when he stayed four days. 116 In the meantime he had prepared 'A Regimen proposd to the Right Reverend my Lord Bishop of Ely: for the gout'. ${ }^{117}$ He suggested that Butts follow "the medium road" rather than pursuing the "exactest temperance" such as Cheyne was then proposing with his milk and vegetable diet. Cheyne wrote of one patient, on a milk and vegetable diet for twenty years, who gave a twelve course dinner for some of his friends:

who thought they were eating Scotch Collops, Partridges, Hares, and Venison, etc., when they eat Nothing but Potatoes, Turnips, Carrots, and Artichokes, cut into these Shapes and dressed with Oil and Oranges, and gave them 5 or 6 different Mineral Waters coloured like so many Kinds of different Wines, only with Cinnamon, Cochineal, and Syrup of Clove, Jelly Flower, and Currant Jellies. ${ }^{118}$

Stukeley ${ }^{119}$ considered that Cheyne's strict vegetarian regimen resulted in "a life scarce vital. a languishing, insipid, \& unsocial state, to those that have been brought up, in the ordinary method of living". His advice was to eat all sorts of meats, but well cooked rather than rare and in small amounts, together with vegetables. Like Cheyne, he continued to stress the importance of milk as a "fine, smooth, oleaginous, animal liquor, made out of vegetables", which "subdues the acid, corrosive ferments in the stomach". He suggested that the diuretic effect allowed "nature to throw off offensive salts by the kidneys. in time it contributes much toward producing a new state of the blood, not subject to the gout". He also recommended water, tea, coffee and spa water. Alcohol, apart from a small quantity of mild soft ale, was to be avoided. Moderate exercise was "absolutely necessary". Stukeley alluded to the importance of keeping regular hours, going to bed early and rising early, the latter particularly in summer. His regimen was said to take two years to slow the gout and, in the meantime, acute attacks were to be treated with the oils, "which much shortens the fitt, takes off the pain, \& effectually saves the joints, from being disabled, from nodes \& chalkstones from contractions of the tendons, from the joints being solder'd together, as two pieces of metal."

There is no record of Bishop Butt's response, but Stukeley's advice was generally ignored. At first he blamed this on the petty jealousies of country people, but he was

\footnotetext{
Cheyne to Samuel Richardson (1733-1743)', The University of Missouri Studies, 1943, 18: 1-137. Letter XLVII, 15 November 1741 , p. 73.

116 Bodl. MSS Eng. misc. d. $719 / 19$, f.3 and e. 125, f.33.

117 BFC. A working draft in Stukeley's handwriting dated 20 April 1741 and consisting of ten leaves, measuring $155 \times 190 \mathrm{~mm}$, written on the rectos with emendations on the versos. Robert Butts (1684-1748), MA (Camb.) 1711, DD 1728, Bishop of Norwich 1733, nominated to Ely, 25 May 1738.

118 Mullett, op. cit., note 115 above, Letter LXXv, 19 November 1742, p. 117-18; for a detailed consideration of Cheyne's regimen and writings see the articles by McCrae and Porter, op. cit., note 113 above.

119 Stukeley, op. cit., note 117 above. There is no evidence that Stukeley and Cheyne ever met and there were none of Cheyne's books in Stukeley's library.
} 


\section{William Stukeley and the gout}

no more successful after returning to London in 1748. In a letter to Dr A. C. Ducarel, attorney, in 1750, the Rev. Francis Wise wrote:

I am obliged to you for literary news, and particularly for your account of Dr. Stukeley's method of treating the gout. I am afraid to venture upon the oils, but shall endeavour to follow the other part of the prescription. ${ }^{120}$

Despite such setbacks, he persevered and through his circle of friends gained introductions to William Pitt, Secretary of State, and Sir Robert Henley, the Lord Keeper, who was to become Lord Chancellor in 1761. Both men suffered from severe gout and Stukeley sought to have them follow his regimen, no doubt believing that success in their cases would vindicate his stand:

December 1, 1758: by desire, I waited on Ld. Keeper Henley. presented a bottle of oleum arthriticum. munday was sennight I sent him my abstract of the treatise on the gout.

9 Sent my MS regimen of the gout to Ld. Keeper.

14 Sent the same to Mr Secretary Pitt. ${ }^{121}$

In his regimen of 9 December 1758, Stukeley appealed to Pitt and Henley to use their reason and consider the consequences of their actions. ${ }^{122}$ Although the letter was mainly concerned with food and drink (but by then forbidding any alcohol at all), there was also mention of air (the night air of the town and the day air of the country being preferable for podagrics), sleep and waking (10 p.m. and sunrise), motion and rest (walking 3 to 4 miles a day or riding thirty miles) and the problem of excretion and retention (stressing the beneficial effects of glandular secretions such as saliva, tears, bile and the mucus from the nose and lungs, in aiding digestion). He failed to refer to mental affections, the sixth non-natural.

By 1760 , Stukeley was referring to the prevention rather than the cure of the gout. In a letter titled 'The Cause and Prevention of the Gout' he wrote:

the world has not thought amiss, in deeming the gout incurable, ie. a fitt of it. for it must be chiefly left to Natures solution. tho' the recovery is much forwarded by unction with oil. now I have found by long feeling \& consideration, that the only way to subdue that formidable malady, is to know the cause $\&$ to prevent it. ${ }^{123}$

The regimen was much the same, avoiding wine and drinking water to dissolve the animal salts, moderation in diet, exercise and attention to the other non-naturals. Stukeley again tried to influence Pitt to follow this regimen when he presented him

${ }^{120}$ F. Wise to A. C. Ducarel, 27 November 1750, in Nichols, op. cit., note 1 above, Lit. illus., iv, p. 442-3. Francis Wise (1695-1767), archaeologist, MA (Oxon.) 1717, BD 1727 and FSA 1749. A. C. Ducarel (1713-1785), DCL 1742, Member College of Advocates 1743, FSA 1737 and FRS 1762.

121 Bodl. MS Eng. misc. e. 138, ff.19-20.

122 Stukeley, op. cit., note 41 above.

123 'On the gout', BFC, Ten leaves, $155 \times 190 \mathrm{~mm}$, in Stukeley's writing and dated 20 February 1760. A working draft, with several alterations on the versos; there is no indication of the proposed recipient. 
with another manuscript on the gout in November $1760 .{ }^{124}$ Pitt generally followed the advice of his own physician, Dr Anthony Addington, and is unlikely to have acted on Stukeley's recommendations. ${ }^{125}$ Henley did not have the time to do so, as William Warburton wrote to Stukeley in 1762 :

Lord Chancellor, who has been on a visit with us for a fortnight or three weeks, has just left us. He spoke of you with great kindness, and believes that the regimen you prescribed to him for his gout would have very good effects, would the business of his station afford him time to pursue it. ${ }^{126}$

Despite these rebuffs Stukeley was convinced that the cause and cure of the gout:

is what I plainly discover'd \& publishd to the world above 20 years agoe: whereof 1000 copys have been sold \& dispersd: yet I cannot boast of any converts: tho' they be satisfyd of the truth: yet they cannot p[er]suade themselves to follow it. they hope nature will mend upon the[m]: a constitution will change for the bett[er], or some more desirable method will be found out, than that of leaving off wine \& good liquors, \& good company; \& abandoning ourselves to solitude $\&$ retirem[en]t. ${ }^{127}$

A belief in the healing power of nature was a corollary of the commonly held belief that gout was not a disease per se, but rather a physiological process for the removal of a toxic substance. Sir Richard Blackmore was one who questioned whether gout deserved "the Appellation of a Disease". ${ }^{128} \mathrm{He}$ also noted that many gouty patients preferred "to take a nauseous Draught of Physick than forbear a pleasant Glass of Wine". ${ }^{129}$ Stukeley blamed physicians, surgeons and apothecaries for discouraging attempts at cure, lest the gout move from the extremities to affect the stomach. So as to prevent this, wine was often recommended in the treatment of gout. Stukeley considered that this was merely "heaping fewel upon the fire". ${ }^{130}$ Some years later William Heberden took a similar line when he commented that the belief arose, "not so much perhaps from a reasonable persuasion of its truth, as from a desire that it should be true, because they [gouty persons] love wine". ${ }^{131}$

Stukeley eventually became completely disillusioned with physic:

124 Bodl. MS Eng. misc. e. 139, f.39.

${ }^{125}$ W. S. Taylor and J. H. Pringle (eds), William Pitt: correspondence, 4 vols, London, 1834-40, vol. 2, pp. 272-3. Anthony Addington (1713-1790) studied medicine at Oxford gaining his MB (1741) and MD (1744). His career is noteworthy for his interest in the treatment of insanity, his involvement in a professional dispute and in a murder trial at Reading, before he moved to London and became FRCP in 1756. In 1788 he was recalled from retirement to consult on the King's madness.

126 W. Gloucester to W. Stukeley, 10 October 1762, in Nichols, op. cit., note 1 above, Lit. illus., ii, pp. 55-6. William Warburton was appointed Bishop of Gloucester in 1759.

${ }^{127}$ BFC. A MS by Stukeley of four leaves, measuring $155 \times 190 \mathrm{~mm}$, written on the rectos, dealing with "reasons why the gout has hitherto been reckond an incurable distemp[er]." Bound with another undated MS of four leaves, headed 'The gout', also in his handwriting, on the " 3 great evacuations in the human body".

${ }_{128}$ R. Blackmore, Discourses on the gout, a rheumatism and the King's evil, London, 1726, p. 64.

129 Ibid., p. 80.

130 Op. cit., note 127 above.

131 W. Heberden, Commentaries on the history and cure of diseases, London, 1802, p. 47. 


\section{William Stukeley and the gout}

$\&$ when we consider the true cause as I have here deliverd it, we see why bolus's pills, diet drinks, emetics, purges \& the whole pharmacopea is administerd to little purpose: they touch not the cause. they only depress. ${ }^{132}$

Such therapeutic endeavours were based on the contemporary belief that, to counter desperate diseases, it was necessary to deplete patients of toxins by bleeding, emesis and purgation, even though this further weakened them. ${ }^{133}$ George Cheyne had also distrusted his colleagues in the medical profession and, in recommending his dietary regimen, he advised Samuel Richardson to ignore the advice of:

Friends, Relations, Doctors, and Apothecaries, who either know Nothing of the Matter, are well under a common Diet, or whose Interest it is, or at least that of the Craft to keep you always ailing or taking Poisonous Stuff ... 134

Criticism of the faculty was widespread. Horace Walpole, for example, complained that, "no limb of the faculty ever laid in ambush to intercept and cut off an illness to come." 135 This was an age when there was increasing emphasis on the prescription of drugs, particularly by the largest group of regular practitioners, the surgeonapothecaries. Although many of the drugs were available in proprietary preparations, regulars insisted that they alone had the knowledge necessary to determine the timing and size of the dose for individual patients in conjunction with an appropriate regimen. ${ }^{136}$ Before his about-turn Stukeley himself had stressed the importance of the physician when advising Richard Butts about the gout: "a vomit, \& a purge are proper to be taken at some intervals. the kind \& manner to be prescribd by a physician, agreable to constitution \& exigence, or to your Lordship's own great judgement \& experience." 137

It was William Buchan who was ultimately most successful in challenging this monopolistic view. ${ }^{138} \mathrm{He}$ pointed out that self-help through attention to regimen was more important than medicines. Buchan criticized physicians, "whose ideas of medicine never rise above the sordid views of a trade". ${ }^{139}$ In revealing their secrets, he claimed that "the affectation of mystery not only renders the medical art more liable to be abused, but likewise retards its progress". ${ }^{140} \mathrm{He}$ encouraged self-medication for "people of better understanding", recommending a small group of medicines, but the main emphasis was on regimen, as a preventive, which Buchan believed was within

\footnotetext{
132 Op. cit., note 127 above.

${ }^{133}$ D. Porter and R. Porter, op. cit., note 10 above, pp. 61-2.

134 Mullett, op. cit., note 115 above, Letter LiII, 10 January 1742, pp. 79-82.

$135 \mathrm{H}$. Walpole to Sir Horace Mann, 15 February 1775, in P. Toynbee (ed.), The letters of Horace Walpole, 16 vols., Oxford, Clarendon Press, 1903-25, vol. 9, pp. 163-6.

136 D. Porter and R. Porter, op. cit., note 10 above, pp. 157-63, for a consideration of prescribing and the case for the supervisory role of the medical practitioner.

${ }^{137}$ Stukeley, op. cit., note 117 above.

138 W. Buchan, Domestic medicine or the family physician, Edinburgh, 1769. For a discussion of its influence and the reaction of the faculty, see Smith, op. cit., note 112 above, and C. J. Lawrence, 'William Buchan: medicine laid open', Med. Hist., 1975, 19: 20-35.

139 Ibid., p. xiv.

140 Ibid., p. viii.
} 


\section{Kevin J. Fraser}

the reach of all. ${ }^{141}$ His advice was within the framework of the non-naturals, although he did not use the term, and he added cleanliness and infections. Many of Buchan's recommendations for gout were similar to those which Stukeley had advocated in his letters to Butts, Henley and Pitt. The major difference was that Buchan advised against all external applications, because of the risk of irregular gout. However, he agreed that vigorous evacuations only weakened the patient, prolonging the attack. There was almost universal agreement on the regimen to be followed between attacks, based on the belief that there was no harm in altering the constitution through attention to the non-naturals and a milk diet.

Stukeley's consideration of the gouty constitution finally persuaded him that the disease was not curable. He reasoned that, as "a Constitution is compounded of the solids as wel as fluids. hence it is that tho the gout proply speakg is destroy'd, yet a tendency wil ever remain." 142 Cheyne had first stressed the importance of patent body solids, the pipes, vascular and gastro-intestinal, and the nerves, to allow the free flow of fluids, which was so important for the animal economy. ${ }^{143}$ Stukeley believed that gout differed from other diseases, such as fever, smallpox, asthma, jaundice and dropsy which, if not terminal, could be "cur'd" by depleting the fluids, and never return. ${ }^{144}$ There was, however, no means of eliminating the tendency to gout in the solids of the body, and this convinced Stukeley that it was hopeless to speak of a cure for the gout. However, it was possible to influence favourably the constitution by exercise, a moderate diet and temperance. Riding was thought to be particularly beneficial for the fluids by exercising the abdominal viscera, promoting the circulation of the vital juices and preventing the stagnation of toxins in the bowel. Walking, by stimulating the circulation, was beneficial for both fluids and solids alike. ${ }^{145}$ In all these things, Stukeley's chief guiding principle was to follow the Hippocratic "golden medium":

Perspiration is good for the gout, but not immoderate sweating, bec' it carrys off the fat. the golden medium seems right for the gout in every thing, liquor, eating, exercise, evacuations. drink above water, below the strength of wine, ie small beer. ${ }^{146}$

\section{STUKELEY, JOHN HILL AND WILLIAM CADOGAN}

The enigmatic John Hill was one member of the faculty to embrace at least some of Stukeley's ideas. Like Stukeley, Hill's father Theophilus had graduated in medicine at Cambridge and later took Holy Orders. He lived at Peterborough and Stukeley often visited him to discuss scientific matters. ${ }^{147}$ Little is known of the formative years of his youngest son John (born in 1714), except that he rebelled against his father and left home when young. This was the first sign of the fierce independence and

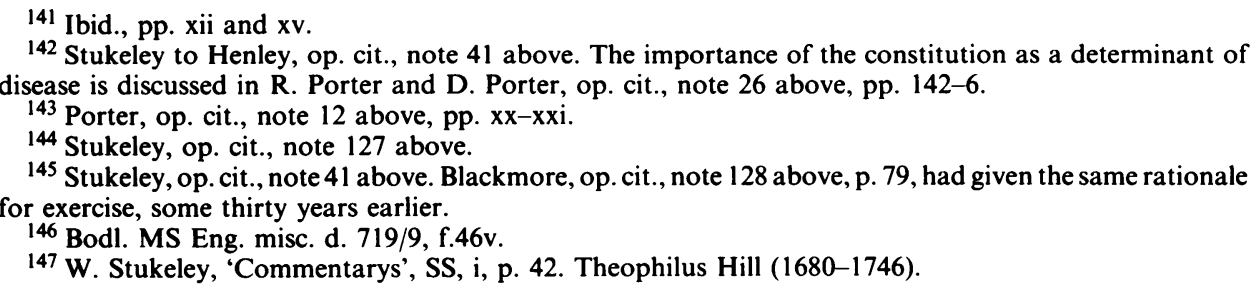




\section{William Stukeley and the gout}

self-righteousness which, over the next fifty years, were to lead to many disputes and unfulfilled ambitions as an actor, poet, playwright, journalist, novelist, apothecary, doctor and scientist. ${ }^{148}$

When Stukeley returned to London in 1748 he and Hill became close friends. Although he was not a member, Hill had attended meetings of the Royal Society regularly since 1746 and he often met Stukeley there and at the regular informal meetings of a small group of literati. ${ }^{149}$ When Hill was banned from the Royal Society in 1750 for criticizing its organization and the standard of the communications, ${ }^{150}$ Stukeley acted as a go-between, keeping Hill informed about the proceedings and conveying messages from him. ${ }^{151}$ One of his reasons for returning to London was to publish some pieces on religion and other subjects and these appeared in Hill's papers, the British Magazine and the London Daily Advertiser. ${ }^{152}$

As Hill suffered from the gout, we can be sure that Stukeley advised him about regimen, particularly as they sometimes dined together. On one occasion, on 7 June 1752 when Stukeley was ill with gout, the Rev. Mr Gifford preached for him and afterwards Hill and Gifford joined him for dinner. ${ }^{153}$ Toward the end of 1758 , possibly as a result of their discussions, Stukeley was placing more emphasis on the importance of regulating the non-naturals other than diet. ${ }^{154}$ It is probably no coincidence that in April of that year Hill had published a book on the management of gout in which he stressed the therapeutic importance of exercise, regular hours of sleep, peace of mind and moderation in all things including food and drink:

Temperance and a quiet mind are the two great articles. They are both in his power; though perhaps there requires a command of himself to enjoy the benefit of either: therefore the patient is to be his own physician, and the best medicine for the gout is a true philosophy. ${ }^{155}$

Although some of Hill's scientific books were well received, many of his medical works were considered to be mere advertisements for his natural remedies and were

148 G. S Rousseau, 'John Hill, universal genius manqué: remarks on his life and times, with a checklist of his works' in The renaissance man in the eighteenth century, Los Angeles, William Andrews Clark Memorial Library, 1978, pp. 45-129.

${ }_{149}$ Royal Society: JBC. 19, 20, for Hill's attendances, 1746-50. W. Stukeley to M. Johnson, 15 May 1750, SGS Letters, Packet No. 88 regarding weekly meetings at the houses of Dr John Hill, Dr James Parsons, Mr Noah Sherwood and Dr Cromwell Mortimer.

${ }_{150}$ C. Emery, “'Sir" John Hill versus the Royal Society', Isis, 1942, 34: 16-20.

${ }^{151}$ Bodl. MSS Eng. misc. e. 129, ff.47-8 and e. 139, f.67.

152 Stukeley wrote a remembrance of the Duke of Montagu, 'On benevolence-some anecdotes of a nobleman lately deceas'd', which was published in the British Magazine, 1749, 4: 431-4. See Bodl. MS Eng. misc. e. 128, f.88 for Stukeley's authorship. He also contributed at least two 'Inspectors' for the London Daily Advertiser, No. 26, 11 April 1751 and No. 71, 29 June 1751: Bodl. MSS Eng. misc. e. 130, f.44 and d. $719 / 12$, f.15.

${ }_{153}$ Bodl. MS Eng. misc. e. 133, f.14. Rev. Andrew Gifford (1700-1784), Pastor of the Eagle Street Baptist Meeting, 1730-1784, FSA, numismatist, DD Aberdeen 1754, and from 1757, assistant librarian of the British Museum.

${ }_{154}$ Stukeley to Henley, op. cit., note 41 above.

${ }^{155}$ [G. Crine], The management of the gout, by a physician from his own case, with the virtues of an English plant Bardana, 2nd ed., London, 1758, p. 48. The book was reviewed in Monthly Review, 1758, 18: 531-2. The first edition was published anonymously. George Crine is shown as the author of the second to fifth editions. The first and fifth editions are held in the library of the Royal College of Surgeons of England. 
published pseudonymously. His work on gout was no exception, for he devoted a chapter to the efficacy of the Burdoch root and George Crine, MD was said to be the author of the first five editions. The book was favourably reviewed and, once its success was established, Hill's name appeared as the author of the sixth edition, which also appeared in $1758 .^{156}$

Stukeley had been exclusively interested in gout and there is nothing to suggest that he ever considered the more general benefits of regimen. He did not live to see self-help become a popular philosophy in the latter part of the eighteenth century, and there is no direct evidence that he influenced any of the principal architects of this movement. However, he lived at Queen Square, nearby the Foundling Hospital, where his close friend, Charles Morton, was a physician. He had negotiated with the Governors of the hospital to obtain some land for a burying ground and they sometimes invited him to Handel's recitals at the hospital. ${ }^{157}$ It seems likely that he would have been acquainted with Morton's colleague, William Cadogan.

In 1771 Cadogan, who was also a Governor of the hospital, aroused considerable interest with his pamphlet, $A$ dissertation on the gout, and all chronic diseases, which was widely read, going through nine editions in the first two years. Cadogan considered that the main causes of all chronic diseases, including gout, were indolence, intemperance and vexation, and he concluded, "if there be any truth or weight in what I have said, the remedies are obvious. Activity, Temperance and Peace of Mind"-principles identical to those propounded by Stukeley and Hill. ${ }^{158}$

Cadogan's lack of originality did not escape John Hill's attention. He reissued his book of 1758 as the eighth edition in 1771, incorporating reference to diet, exercise and temper in a revised title The management of the gout, in diet, exercise and temper. ${ }^{159}$ Although the importance of these factors had been stressed in the earlier editions of his book, Hill re-emphasised them, including reference to all three in many places in the text where previously only one or two were mentioned. For example, "Altho' rich food and little exercise naturally will in time bring on the gout; they have not this effect universally" 160 became, "Although rich food, little exercise, and

The second edition is in BFC. The Wellcome Institute for the History of Medicine, London holds the third and fourth editions. All editions have identical pagination.

${ }_{156} \mathrm{~J}$. Hill, The management of the gout, with the virtues of Burdock root, 6th ed., London, 1758. Copies of this edition are in the National Library of Medicine, Washington, and the Archibald Church Medical Library, Chicago. The following note is on the verso of the title page of the latter copy: "This, and the Structure of the Nerves, being the Author's first Medical Works, were, through diffidence, originally publish'd with the imaginary Names of Crine and Uvedale."

${ }^{157}$ Bodl. MSS Eng. misc. e. 133, f.8, e. 137, f.83. and e. 667/3, f.19v. Charles Morton (1716-1799), MD (Leyden) 1748, FSA, FRS (1752) and secretary of the Royal Society, 1760-1764. He was appointed as physician to the Foundling Hospital in 1754 and as under-librarian to the British Museum in 1756, a post he held until he was appointed principal librarian in 1776.

${ }_{158}$ William Cadogan, $A$ dissertation on the gout, and all chronic diseases, jointly considered, as proceeding from the same causes; What those casues are; and a rational and natural method of cure proposed. Addressed to all invalids, London, 1771, p. 69. William Cadogan (1711-1797), MD (Leyden) 1732, moved to London from Bristol in 1750 and established a very successful practice. He became FRS (1752), physician to the Foundling Hospital (1754), and FRCP (1758).

$159 \mathrm{~J}$. Hill, The management of the gout, in diet, exercise, and temper; with the virtues of Burdock root, taken in the manner of tea, 8th ed., corrected and enlarged, London, 1771.

160 [Crine], op. cit., note 155 above, p. 6. 
sorrow, may often in time bring on the gout originally; they have not this effect universally". 161

It has been suggested that Cadogan plagiarized Hill's work. ${ }^{162}$ There are certainly many similarities and there can be no question that Hill had these in mind when he revised his book. Where there were differences such as Cadogan's belief that gout was not an hereditary disorder and that rare, rather than well cooked, meat was preferable, Hill answered them pointedly. There were overtones of one of Stukeley's pieces for the London Daily Advertiser, an "Inspector" on the superiority of man to animal, ${ }^{163}$ in Hill's argument against Cadogan's recommendation for rare meat:

he who would tell us to do this, because the beasts of prey eat them bleeding, and are strong; might as well bid us, in imitation of the same creatures, to go naked; they do their best: but God has given us reason. ${ }^{164}$

Cadogan considered gout as a disease "of the strongest and best constitution" but did not believe that it was hereditary. ${ }^{165}$ Hill responded by including a new paragraph:

The gout oftenest attacks the best constitutions and is most violent in the strongest. We bring the seeds of it often into the world with us, together with the materials of that strength; and though intemperance encreases it always, and often brings it on before its time; no regularity of life can obviate its appearance, where there is that parental taint, at some time or other. ${ }^{166}$

Hill did not directly accuse Cadogan of plagiarism, perhaps because of such differences and the realization that books of this genre could not be traced to a single source. The fact that Cheyne had preached a similar message to polite society fifty years earlier was not lost on Samuel Johnson, who considered that Cadogan's essay was "only Dr. Cheyne's book told in a new way". ${ }^{167}$ There were also others, such as Sir Richard Blackmore who had railed against the "pernicious Helps of Luxury and Excess", which he realized were largely responsible for the gout. ${ }^{168}$ Over-indulgence in food and alcohol was habitual in Georgian England and, together with lack of exercise, accounted for the frequency of gout and obesity. These were the most obvious medical consequences of luxury, but civilization had also produced other diseases, notably stomach conditions and nervous disorders. Whereas Stukeley apparently ignored these, Cheyne and later advocates of self-help through moderation, notably Buchan, were equally concerned about them. ${ }^{169}$

${ }^{161}$ Hill, op. cit., note 159 above, p. 11.

162 G. S. Rousseau (ed.), The letters and papers of Sir John Hill, New York, AMS Press, 1982, p. 169.

163 'Inspector No. 26', London Daily Advertiser, 11 April 1751.

${ }^{164}$ Hill, op. cit., note 159 above, p. 23.

${ }_{165}$ Cadogan, op. cit., note 158 above, p. 13.

166 Hill, op. cit., note 159 above, p. 14 .

167 G. Hill (ed.), Boswell's Life of Johnson, rev. and enl. ed. L. F. Powell, 6 vols., Clarendon Press, Oxford, 1934-50, vol. 5, p. 210. The English malady was the only book by Cheyne in Johnson's library. Although it primarily addressed nervous disorders Cheyne frequently referred to other chronic diseases, including gout.

168 Blackmore, op. cit., note 128 above, p. 53.

169 Buchan, op. cit., note 138 above. For Cheyne see Porter (ed.), op. cit., note 12 above. 
Although Cadogan's book was primarily concerned with gout, he also referred to other chronic diseases. Considering that it contained mainly unpopular and old advice it was surprisingly successful, going through numerous editions at home and abroad. Many pamphlets, mainly critical, were published in reply. ${ }^{170}$ There is probably no single reason why Cadogan attracted more attention than earlier writers, such as Cheyne, Stukeley and Hill. The criticism of luxury on political and social grounds was coming to a head and Cadogan's book certainly introduced a medical argument into the debate at an opportune time. ${ }^{171}$ Coming as it did from a respected and successful member of the medical establishment, it provoked what might be seen as a final and desperate show of indignation on the part of the upper classes and their physicians in the face of changing social mores. If the popular acceptance of William Buchan's book is any guide, the working classes probably needed less persuasion, despite their upward social aspirations. In the event, the excesses of the age were being curbed by the end of the century. Stukeley deserves to be remembered for his part in the debate and for his autobiographical account of the gout, an analysis of which provides a comprehensive overview of the rationale underlying the practice of Georgian medicine.

170 John B. Blake, A short title catalogue of eighteenth-century printed books in the National Library of Medicine, U.S. Department of Health, Education and Welfare, National Library of Medicine, Washington, 1979, pp. 73-4. Apart from eleven London editions there were several American imprints and French, German, Dutch and Swedish translations. For pamphlets published in reply see J. Rendle-Short, 'William Cadogan, eighteenth-century physician', Med. Hist., 1960, 4: 288-309. The bibliography on gout in Sir John Forbes, A manual of select medical bibliography, London, 1835, columns 161-2, is another useful source.

${ }^{171}$ J. Sekora, Luxury: the concept in western thought, Eden to Smollett, Baltimore, Johns Hopkins University Press, 1977. As Rousseau, op. cit., note 113 above, has pointed out, Sekora did not consider the medical aspects of luxury. 